\title{
Protein Requirements in Preterm Infants: Effect of Different Levels of Protein Intake on Growth and Body Composition
}

\author{
NICHOLAS D. EMBLETON AND RICHARD J. COOKE \\ Newcastle Neonatal Service, Department of Child Health, Royal Victoria Infirmary, University of \\ Newcastle upon Tyne NE1 4LP, U.K.
}

\begin{abstract}
This study compares growth and body composition in preterm infants ( $\leq 1750 \mathrm{~g}$ birth weight, $\leq 34 \mathrm{wk}$ gestation) fed three iso-caloric formulas $(80 \mathrm{kcal} / 100 \mathrm{~mL})$ with different protein concentrations $(\mathrm{A}=3.3 \mathrm{~g} / 100 \mathrm{kcal}, \mathrm{B}=3.0 \mathrm{~g} / 100 \mathrm{kcal}, \mathrm{C}=2.7$ $\mathrm{g} / 100 \mathrm{kcal})$. The study began when full enteral feeding (150 $\mathrm{mL} / \mathrm{kg} / \mathrm{d}$ ) was established and lasted until term plus $12 \mathrm{wk}$ corrected age $(T+12$ wca). Nutrient intake was closely monitored throughout the study; daily during initial hospital stay and following discharge averaged between each clinic visit. Anthropometry and serum biochemistries were determined weekly during initial stay and at each clinic visit. Body composition was measured after hospital discharge and at $\mathrm{T}+12$ wca. Seventyseven infants were recruited. No differences were detected in birth/enrollment characteristics between the groups. Protein intake was closely paralleled by changes in serum urea nitrogen and differed between the groups. Infants in group A were heavier and longer and had greater head circumference at discharge, but this was confounded by a slightly older corrected age in this group. There were no significant anthropometric differences at term or $\mathrm{T}+12$ wca. No differences were detected in body
\end{abstract}

\section{ABSTRACT}

composition between the groups following discharge or at $\mathrm{T}+$ 12 wca. An intake of $3.3 \mathrm{~g} / 100 \mathrm{kcal}$ appears safe and may promote increased growth before initial hospital discharge. After discharge, intakes greater than $2.7 \mathrm{~g} / 100 \mathrm{kcal}$ do not appear to offer clear advantage. Further studies are needed to more precisely define protein requirements in these nutritionally at-risk infants. (Pediatr Res 58: 855-860, 2005)

$\quad$ Abbreviations
AGA, appropriate for gestational age
BMC, bone mineral content
DEXA, dual energy X-ray absorptiometry
FM, fat mass
LM, lean mass
OFC, occipitofrontal circumference
SDS, standard deviation score
SGA, small for gestational age
SUN, serum urea nitrogen
wca, weeks corrected age

Protein requirements for preterm infants are substantially higher than for the term infant but, at a given body weight or gestational age, remain poorly defined. Recommendations vary from 2.25 to $3.6 \mathrm{~g} / 100 \mathrm{kcal}(1-3)$, but these are primarily based on requirements for maintenance and normal growth with little allowance made for "catch-up" growth requirements.

In a prospective evaluation of dietary intake and growth, our group has shown that it takes time to establish adequate dietary intakes, and that preterm infants accrue an inevitable protein deficit that is strongly correlated with postnatal growth retardation during initial hospital stay (4). Given the magnitude of

Received March 13, 2003; accepted April 7, 2005.

Correspondence: N.D. Embleton, M.D., Newcastle Neonatal Service, Department of Child Health, Ward 35 Royal Victoria Infirmary, University of Newcastle upon Tyne NE1 4LP, U.K.; e-mail: n.d.embleton@ncl.ac.uk

This study was supported by funding from Nutricia Ltd., Trowbridge, Wiltshire, U.K.

DOI: 10.1203/01.PDR.0000182586.46532.7C this protein deficit, up to $30 \mathrm{~g} / \mathrm{kg}$ at the point of hospital discharge, we speculated that current recommendations systematically underestimated real needs in these infants.

In a randomized, controlled trial examining the effects of dietary intake on growth in preterm infants, our group has also shown that preterm infants fed a preterm formula after hospital discharge grew better than infants fed a term infant formula (5). Improvements in growth and lean body mass appeared to be related to differences in protein intake, further supporting the idea that inadequate protein intake is a common problem in these high-risk infants $(5,6)$.

Given the critical importance of nutrition during early life (7), we decided to examine the effects of different levels of dietary protein on growth and body composition in these high-risk infants. It was hypothesized that preterm infants fed a formula containing $3.3 \mathrm{~g} / 100 \mathrm{kcal}$ of protein would gain more weight than those fed formulas containing 3.0 and $2.7 \mathrm{~g} / 100$ kcal of protein. 


\section{METHODS}

This prospective, randomized, and controlled trial was conducted at the Special Care Baby Unit, Royal Victoria Infirmary, Newcastle upon Tyne. Infants were recruited over a 2-y period starting in December 1997. The study was approved by the Joint Ethics Committee of the Newcastle and North Tyneside Health Authority. Written informed consent was obtained from the parent(s) or guardian. The study began once the study formula was fed and lasted until 12 wk post term ( $\mathrm{T}+12 \mathrm{wca})$.

Preterm infants ( $\leq 34$ wk gestation, $\leq 1750 \mathrm{~g}$ birth weight) were considered eligible. The study therefore included infants who would be considered to be SGA and AGA. Gestation was determined using maternal dates and intrauterine ultrasound, and we defined postmenstrual age (PMA) from the beginning of the last menstrual period. Only those infants tolerating an enteral intake of $\geq 150 \mathrm{~mL} / \mathrm{kg} / \mathrm{d}$ for $\geq 48 \mathrm{~h}$ and with a current weight of $\geq 1000 \mathrm{~g}$ were enrolled. Infants requiring ventilator support, an $\mathrm{FiO}_{2} \geq 0.4$, or corticosteroid therapy were excluded. Infants with a congenital anomaly, significant gastrointestinal pathology, or significant neurologic abnormality were also excluded.

Parents who expressed a desire to formula feed their infants were approached by a single investigator (N.D.E.) and provided with an information sheet. Witnessed signed consent was not obtained until parents had at least $24 \mathrm{~h}$ to consider the study. Infants were stratified by birth weight $(<1250 \mathrm{~g}$ or $1250-1750 \mathrm{~g}$ ) and randomized to one of three treatment groups using sealed, opaque envelopes labeled sequentially by a member of secretarial staff. Ready-to-feed formula was provided in cartons containing $24 \times 100 \mathrm{~mL}$ bottles color coded by the manufacturer. Infants were exclusively formula fed. The compositions of the study formulas (manufactured by Nutricia Ltd., Trowbridge, Wiltshire, U.K.) are presented in Table 1. The formulas differed primarily in protein content $(\mathrm{A}=3.3 \mathrm{~g} / 100 \mathrm{kcal}, \mathrm{B}=3.0 \mathrm{~g} / 100 \mathrm{kcal}, \mathrm{C}=2.7$ $\mathrm{g} / 100 \mathrm{kcal})$. The protein content of the formulas was modified bovine milk protein with a 60:40 ratio of whey proteins to caseins. Calorie content was maintained at $80 \mathrm{kcal} / 100 \mathrm{~mL}$ by minor variations in the fat content. Otherwise, the formulas were identical in osmolality $\left(293 \mathrm{mOsmol} / \mathrm{kg} \mathrm{H}_{2} \mathrm{O}\right)$ and mineral and vitamin content, and all contained taurine, nucleotides, and long-chained polyunsaturated fats.

During initial hospital stay, nutrient intake was monitored on a daily basis to ensure that an intake of $\sim 150 \mathrm{~mL} / \mathrm{kg} / \mathrm{d}$ was maintained. After hospital discharge, parents were provided with 8-10 individually labeled and preweighed cartons with instructions to shake the bottle thoroughly and feed to appetite. A 24-h service was provided to deal with any problems that arose and regular contact was maintained between each clinic visit by telephone.

Infants were reviewed weekly during hospital stay, twice weekly between discharge and term, and every 4 wk until $\mathrm{T}+12$ wca by a single observer (N.D.E.). During hospital stay, intake of formula was measured daily. Protein intake was calculated by multiplying the volume of intake by protein density as provided by the manufacturer. The cumulative calorie and protein deficit was calculated as previously described (4). Following discharge, the volume of intake was calculated by subtracting the weight of the returned from the delivered cartons between visits. Intake volume $(\mathrm{mL} / \mathrm{kg} / \mathrm{d})$ between clinic visits after discharge was averaged for that time period (total volume divided by average weight).

During initial hospital stay, infants were weighed on alternate days while crown-heel length and OFC were determined weekly (5). During initial stay, serum biochemistry ( $\mathrm{SUN}$, creatinine, total serum protein, serum albumin, $\mathrm{pH}$, and base deficit) was measured weekly and analyzed using standard laboratory techniques. Because infants feeding ad libitum after discharge may consume large volumes of milk, it was considered important to monitor SUN. Anthropometry and biochemical determinations were therefore performed at each clinic visit. If uremia (SUN $>6 \mathrm{mM}$ ) or metabolic acidosis (base deficit $\geq 4$ ) was noted, then serum biochemistries were repeated, and plasma ammonia and amino acids were also determined. If uremia or acidosis had persisted, or had there been hyperammonemia, then the study formula would have been discontinued. This never occurred.

Table 1. Study formula composition

\begin{tabular}{lccc}
\hline & A & B & C \\
\hline Energy $(\mathrm{kcal} / 100 \mathrm{~mL})$ & 80 & 80 & 80 \\
Protein $(\mathrm{g} / 100 \mathrm{~mL})$ & 2.6 & 2.4 & 2.2 \\
Fat $(\mathrm{g} / 100 \mathrm{~mL})$ & 4.3 & 4.4 & 4.5 \\
\hline
\end{tabular}

The formula all contained DHA and AA and nucleotides, and the composition per $100 \mathrm{~mL}$ were identical for the following: carbohydrate $(7.9 \mathrm{~g})$, calcium $(100 \mathrm{mg})$, phosphorus $(50 \mathrm{mg})$, magnesium $(10 \mathrm{mg})$, iron $(0.9 \mathrm{mg})$, zinc $(0.7 \mathrm{mg})$, and vitamin $\mathrm{D}(5.0 \mu \mathrm{g})$ and contained standard trace element and vitamin concentrations.
Parents were specifically asked to report feeding problems, e.g. vomiting, regurgitations, constipation/diarrhea, or other health problems, e.g. fever, lethargy, etc. Parents were encouraged to not commence weaning until the study had finished. The date of, and reasons for, weaning were recorded.

Body composition was determined after initial hospital discharge and at the end of the study using whole-body DEXA (Hologic QDR 2000, Hologic Inc., Waltham, MA; Infant Whole Body software v5.68P) and the technique previously described (4). The following compositional variables were reported: LM, FM, percentage FM, BMC, and bone mineral density (BMD). The difference between the two scans allowed calculation of weight gain composition. Because an increase in apparent BMC may be caused by movement artifact (8), re-analysis was planned where scans of poor quality were excluded. Scans of poor quality were defined as those with ratio of measured to DEXA weight of $<0.95$ or $>1.05$, visible movement artifact, or more than two breaks in bony outline of the printed image.

Data were entered into a specially designed database and thoroughly checked to ensure accuracy. Because of variation in gestational and postnatal age, weight, length, and OFC were converted to SDS using current British references (9). SGA was defined as weight $\operatorname{SDS}<-2$ at that gestation. Data were analyzed on an intention to treat basis. Results are expressed as mean \pm SD except where stated.

In the absence of published data for infants consuming such formula until $\mathrm{T}+12 \mathrm{wca}$, we used data from our previous studies as a guide, with weight gain as the primary outcome variable. A weight difference of $5 \mathrm{~g} / \mathrm{d}$ was considered to be significant and it was calculated that $\sim 30$ infants per group would be needed to detect a difference at the $5 \%$ level with a power of $80 \%$.

To avoid errors associated with week-to-week observer variability and the errors associated with repeated measures analysis, summary measures were calculated for weight gain and length gain by creating regression slopes for individual infants (10). Data on weight and length gain from these slopes was then used as the raw data for analysis. Growth was analyzed by dividing the study into three periods: enrollment to discharge, enrollment to term, and term to $T+12$ wca. Visual inspection determined that weight and length gain were virtually linear during these different periods.

Group differences in characteristics at birth and enrollment were analyzed using ANOVA for continuous data and Mann-Whitney test for nonparametric data. ANOVA was used to compare anthropometric variables and rates of gain, and also used to compare SDS for weight, length, and OFC. Posthoc comparisons were made using the Bonferroni-Dunn adjustment for multiple comparisons. Unpaired $t$ test was used to compare differences between the sexes.

\section{RESULTS}

Eighty-eight formula-fed infants met eligibility criteria during the study. Nine sets of parents declined to participate and two sets of parents were not approached (study investigator not available). Therefore, 77 infants were enrolled. Baseline characteristics of the enrolled and nonenrolled infants did not differ. Infant characteristics are presented in Table 2. No significant differences were detected between groups $\mathrm{A}, \mathrm{B}$, and $\mathrm{C}$ at birth or enrollment. After initial hospital discharge, one infant died with a postmortem diagnosis of sudden unexpected death in infancy, and two other infants were readmitted to hospital because of acute viral illness requiring mechanical ventilation. For these three cases, data collected to the point of death or hospital admission were included in the analysis.

During hospital stay, intake volumes were maintained at $150-165 \mathrm{~mL} / \mathrm{kg} / \mathrm{d}$ until the infants were transitioned from gavage to demand feeds. After discharge, average intakes increased to a peak of $185 \pm 31 \mathrm{~mL} / \mathrm{kg} / \mathrm{d}$ at a corrected age of term, and then declined. Protein intake data are presented in Figure 1. Note that because infants were enrolled at differing corrected ages there was a variable length of time between trial "start" and 36 wca. Significant differences in protein intake were detected between groups: A $>$ B $(0.5 \mathrm{~g} / \mathrm{kg} / \mathrm{d}, p<$ $0.0001)$. During the study period, infants in group B consumed slightly less $(157 \pm 29 \mathrm{~mL} / \mathrm{kg} / \mathrm{d})$ than infants in groups A (164 $\pm 29 \mathrm{~mL} / \mathrm{kg} / \mathrm{d})$ or $\mathrm{C}(161 \pm 31 \mathrm{~mL} / \mathrm{kg} / \mathrm{d})$, but because of 
Table 2. Characteristics of study infants at birth and enrollment

\begin{tabular}{lccc}
\hline & $\begin{array}{c}\text { Group A } \\
(\mathrm{n}=25)\end{array}$ & $\begin{array}{c}\text { Group B } \\
(\mathrm{n}=26)\end{array}$ & $\begin{array}{c}\text { Group C } \\
(\mathrm{n}=26)\end{array}$ \\
\hline Male & 17 & 15 & 15 \\
At birth: & & & \\
$\quad$ Birthweight (g) & $1386 \pm 330$ & $1379 \pm 271$ & $1414 \pm 286$ \\
Gestation (weeks) & $30 \pm 2$ & $30 \pm 2$ & $31 \pm 2$ \\
Age at first feed (days)* & $1(0-3)$ & $1.5(0-7)$ & $1(0-3)$ \\
Age at full feeds (days)* & $9(2-19)$ & $7(3-26)$ & $6(4-16)$ \\
Maximum cumulative & $17.6 \pm 8.4$ & $15.3 \pm 8.7$ & $14.6 \pm 4.9$ \\
$\quad$ protein deficit (g/kg) & & & \\
Maximum cumulative & $512 \pm 193$ & $501 \pm 307$ & $445 \pm 181$ \\
$\quad$ calorie deficit (kcal/kg) & & & \\
Trial enrollment: & & & \\
PMA (days) & $242 \pm 14$ & $236 \pm 13$ & $245 \pm 13$ \\
PNA (days) & $27 \pm 18$ & $23 \pm 9$ & $23 \pm 14$ \\
Weight (g) & $1879 \pm 471$ & $1676 \pm 382$ & $1852 \pm 570$ \\
SDS Weight & $-1.3 \pm 1.0$ & $-1.5 \pm 0.9$ & $-1.7 \pm 0.9$ \\
Length (cm) & $41.9 \pm 2.4$ & $41.6 \pm 2.5$ & $42.1 \pm 2.6$ \\
SDS Length & $-2.3 \pm 1.3$ & $-1.9 \pm 1.0$ & $-2.4 \pm 1.1$ \\
Head circumference (cm) & $31.2 \pm 1.9$ & $30.5 \pm 1.9$ & $31.1 \pm 1.9$ \\
$\quad$ SDS Head & $-0.2 \pm 1.0$ & $-0.4 \pm 1.0$ & $-0.5 \pm 0.9$ \\
\hline
\end{tabular}

SDS $=$ standard deviation score; data presented as mean \pm SD except for skewed data denoted by * where median (range) presented. Analysis: ANOVA for continuous data; Mann-Whitney U for nonparametric data. There were no significant differences between the groups. PMA: post menstrual age; PNA: post natal age.

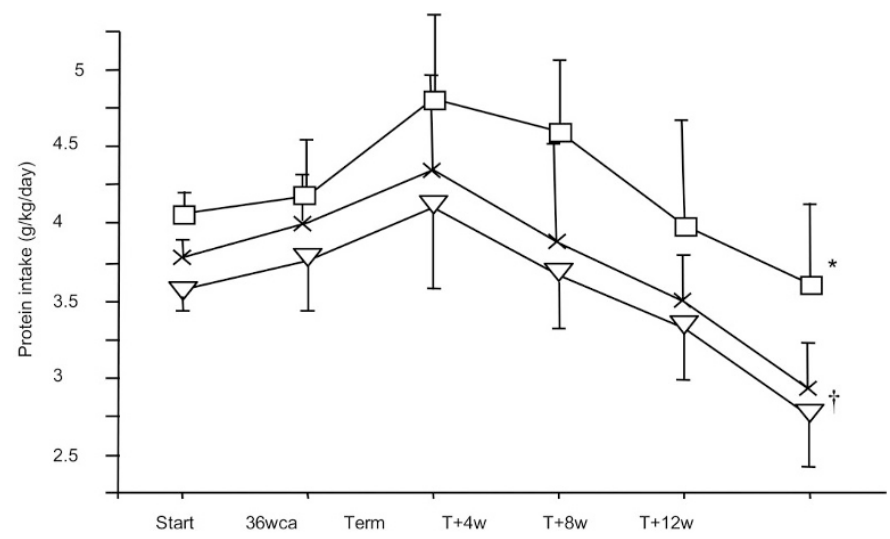

Figure 1. Protein intake during course of the study period split by formula group. Data points represent mean $\pm \mathrm{SD}$. There were significant differences between the groups $\mathrm{A}>\mathrm{B}$ and $\mathrm{A}>\mathrm{C},{ }^{*} p<0.0001 ; \mathrm{B}>\mathrm{C}, \dagger p<0.05$ (ANOVA). $\square-\mathrm{A} ;-\times \mathrm{B} ; \square-\mathrm{C}$.

differing protein densities there was still a difference between the groups: $\mathrm{B}>\mathrm{C}(0.22 \mathrm{~g} / \mathrm{kg} / \mathrm{d}, p<0.05)$. Intake volumes were greater in boys than girls at all visits after discharge, with the greatest difference occurring at term (boys: $191 \mathrm{~mL} / \mathrm{kg} / \mathrm{d}$; girls: $175 \mathrm{~mL} / \mathrm{kg} / \mathrm{d}$ ).

Three infants, all in group A, developed uremia (SUN $>6$ $\mathrm{mM})$. None of these infants developed metabolic acidosis or raised ammonia or had abnormal plasma amino acid profiles. SUN normalized in all infants without intervention (for two infants within $2-3 \mathrm{~d}$, and one infant within $10 \mathrm{~d}$ ). Changes in SUN were associated with the level of protein intake and were closely correlated, especially at term (see Fig. 2). SUN increased during the initial study period, except for group C, where it initially decreased, reached baseline levels at 36-38 wca, and then increased. During the study period until $\mathrm{T}+12$ wca, SUN differed between the groups (A $>\mathrm{B}>\mathrm{C} ; p<$

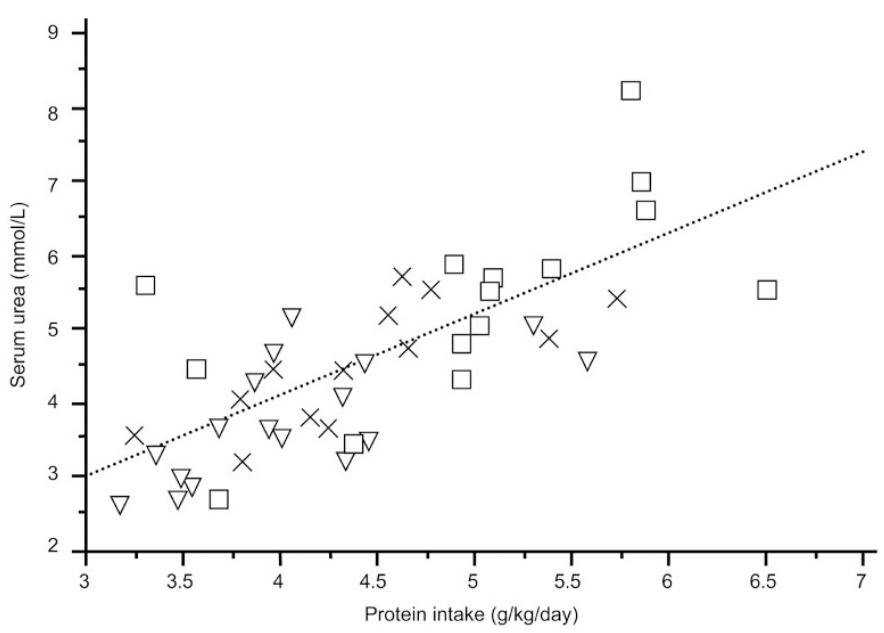

Figure 2. Correlation between protein intake and SUN at a corrected age of term split by formula group. Note the three infants with SUN $>6 \mathrm{mM}$ all in group A. The regression line for all the infants is dotted. SUN $(\mathrm{mmol} / \mathrm{L})=$ $-0.287+1.1 *$ protein intake $(\mathrm{g} / \mathrm{kg} / \mathrm{d}) ; R^{2}=0.54, p<0.0001 . \square \mathrm{A} ; \times \mathrm{B}$; $\nabla \mathrm{C}$.

0.0001, ANOVA) but not between the sexes. No differences were detected in total serum protein or albumin between A, B, and $\mathrm{C}$ or between the sexes.

At discharge, infants in group A were heavier and longer, and had greater OFC and weight SDS than infants in groups B or C, although their corrected age was 6-7 d older (Table 3). Weight gain (grams per day) in all groups was higher than the equivalent in utero fetus [30.7 g/d at 32-36 wk (11)], and was highest in group A, although the group differences were not significant. For all groups, these gains resulted in increases for both weight and length SDS of 0.5 compared with their score at trial enrollment.

Infants in group A remained heavier and longer at term than groups $\mathrm{B}$ or $\mathrm{C}$, but these differences were no longer significant (Table 4 ) and by $\mathrm{T}+12$ wca group differences were no longer apparent (Table 5). Average weight gains during the study, calculated from the difference in weight at the start and $\mathrm{T}+12$ wca, were greater for boys than girls $(31 \mathrm{~g} / \mathrm{d}$ versus $29 \mathrm{~g} / \mathrm{d} ; p$ $=0.015$ ). Figure 3 shows the trend for absolute weight SDS

Table 3. Anthropometry at discharge

\begin{tabular}{lccc}
\hline & $\begin{array}{c}\text { Group A } \\
(\mathrm{n}=25)\end{array}$ & $\begin{array}{c}\text { Group B } \\
(\mathrm{n}=26)\end{array}$ & $\begin{array}{c}\text { Group C } \\
(\mathrm{n}=26)\end{array}$ \\
\hline Weight $(\mathrm{g})$ & $2733 \pm 40$ & $2371 \pm 452$ & $2263 \pm 468^{*}$ \\
Length $(\mathrm{cm})$ & $46.1 \pm 2.2$ & $44.9 \pm 2.2$ & $44.0 \pm 2.0^{*}$ \\
OFC $(\mathrm{cm})$ & $34.3 \pm 1.4$ & $33.3 \pm 1.6$ & $32.9 \pm 1.7^{*}$ \\
PMA (days) & $263 \pm 10$ & $256 \pm 12$ & $257 \pm 11^{*}$ \\
PNA (days) & $49 \pm 20$ & $42 \pm 18$ & $35 \pm 16^{*}$ \\
SDS weight & $-0.6 \pm 1.0$ & $-1.0 \pm 0.8$ & $-1.3 \pm 0.9^{*}$ \\
SDS length & $-1.4 \pm 1.1$ & $-1.5 \pm 0.9$ & $-2.0 \pm 0.9$ \\
Weight gain $\dagger$ (g/day) & $41.6 \pm 6.6$ & $37.2 \pm 6.1$ & $39.8 \pm 6.8$ \\
Length gain $\dagger(\mathrm{cm} /$ week) & $1.3 \pm 0.3$ & $1.2 \pm 0.3$ & $1.3 \pm 0.3$ \\
SDS weight gain§ & $0.7 \pm 0.5$ & $0.6 \pm 0.5$ & $0.5 \pm 0.4$ \\
SDS length gain§ & $0.7 \pm 0.4$ & $0.5 \pm 0.5$ & $0.5 \pm 0.5$ \\
\hline
\end{tabular}

Data presented as mean $\pm \mathrm{SD}$. $\dagger$ Gain in weight and length calculated from regression slopes for individual infants from trial enrollment to discharge; $\S$ gain in SDS $=$ SDS (start of trial)-SDS (discharge). Differences between groups assessed using ANOVA (Bonferroni-Dunn); * = significant difference $p<0.0167$ A $>$ B or C. PMA: post menstrual age; PNA: post natal age. 
Table 4. Anthropometry at term

\begin{tabular}{lccc}
\hline & $\begin{array}{c}\text { Group A } \\
(\mathrm{n}=24)\end{array}$ & $\begin{array}{c}\text { Group B } \\
(\mathrm{n}=26)\end{array}$ & $\begin{array}{c}\text { Group C } \\
(\mathrm{n}=24)\end{array}$ \\
\hline Weight $(\mathrm{g})$ & $3397 \pm 573$ & $3206 \pm 462$ & $3216 \pm 429$ \\
Length $(\mathrm{cm})$ & $48.6 \pm 2.4$ & $48.4 \pm 1.9$ & $47.9 \pm 2.3$ \\
OFC $(\mathrm{cm})$ & $36.2 \pm 1.3$ & $36.0 \pm 1.3$ & $35.6 \pm 1.4$ \\
PMA (days) & $281 \pm 4$ & $280 \pm 5$ & $281 \pm 5$ \\
PNA (days) & $67 \pm 17$ & $67 \pm 15$ & $59 \pm 12$ \\
SDS weight & $-0.3 \pm 1.2$ & $-0.6 \pm 0.9$ & $-0.7 \pm 0.8$ \\
SDS length & $-1.2 \pm 1.2$ & $-1.2 \pm 0.9$ & $-1.5 \pm 1.0$ \\
Weight gain $\dagger(\mathrm{g} /$ day) & $38.3 \pm 7.3$ & $35.2 \pm 5.9$ & $37.1 \pm 5.8$ \\
Length gain $\dagger(\mathrm{cm} /$ week $)$ & $1.2 \pm 0.2$ & $1.1 \pm 0.2$ & $1.1 \pm 0.2$ \\
SDS weight gain§ & $1.0 \pm 0.7$ & $0.9 \pm 0.6$ & $1.0 \pm 0.5$ \\
SDS length gain§ & $1.0 \pm 0.5$ & $0.8 \pm 0.5$ & $0.9 \pm 0.6$ \\
\hline
\end{tabular}

Data presented as mean $\pm \mathrm{SD}$. $\dagger$ Gain in weight and length calculated from regression slopes for individual infants from trial enrollment to term; $\S$ gain in SDS $=$ SDS (start of trial)-SDS (term). There were no significant differences between the groups. PMA: post menstrual age; PNA: post natal age.

Table 5. Anthropometry at 12 weeks corrected age

\begin{tabular}{lccc}
\hline & $\begin{array}{c}\text { Group A } \\
(\mathrm{n}=24)\end{array}$ & $\begin{array}{c}\text { Group B } \\
(\mathrm{n}=24)\end{array}$ & $\begin{array}{c}\text { Group C } \\
(\mathrm{n}=25)\end{array}$ \\
\hline Weight $(\mathrm{g})$ & $5740 \pm 832$ & $5668 \pm 814$ & $5606 \pm 592$ \\
Length $(\mathrm{cm})$ & $58.4 \pm 2.1$ & $58.8 \pm 2.3$ & $58.1 \pm 2.4$ \\
OFC $(\mathrm{cm})$ & $41.3 \pm 1.4$ & $41.2 \pm 1.2$ & $40.9 \pm 1.2$ \\
PMA (days) & $368 \pm 10$ & $369 \pm 10$ & $370 \pm 10$ \\
PNA (days) & $152 \pm 17$ & $155 \pm 16$ & $147 \pm 14$ \\
SDS weight & $-0.5 \pm 1.3$ & $-0.5 \pm 1.1$ & $-0.6 \pm 0.8$ \\
SDS length & $-0.9 \pm 1.1$ & $-0.7 \pm 1.0$ & $-1.0 \pm 1.0$ \\
Weight gain $\dagger(\mathrm{g} /$ day) & $28.3 \pm 5.7$ & $28.2 \pm 5.9$ & $28.8 \pm 4.0$ \\
Length gain $\dagger(\mathrm{cm} /$ week $)$ & $0.8 \pm 0.1$ & $0.8 \pm 0.1$ & $0.8 \pm 0.1$ \\
SDS weight gain§ & $1.0 \pm 0.9$ & $0.9 \pm 0.8$ & $1.1 \pm 0.8$ \\
SDS length gain§ & $1.3 \pm 0.7$ & $1.2 \pm 0.7$ & $1.4 \pm 0.7$ \\
\hline
\end{tabular}

Data presented as mean $\pm \mathrm{SD}$. $\dagger$ Gain in weight and length calculated from regression slopes for individual infants between discharge and $\mathrm{T}+12 \mathrm{w}$; gain in SDS $=$ SDS (start of trial)-SDS $(T+12 \mathrm{w})$. There were no significant differences between the groups. PMA: post menstrual age; PNA: post natal age.

during the study with slightly higher initial increases in group A. However, there were no overall differences in weight gain during the study period to $\mathrm{T}+12$ wca.

Of the 77 infants, $10(13 \%)$ were SGA at birth and $26(34 \%)$ were SGA at enrollment, but only $12(16 \%)$ remained SGA at discharge. Of the 74 infants reviewed at term, only 7 (9\%) remained SGA. Infants who were SGA at birth showed similar weight catch-up at term to those born AGA. SGA infants showed continued catch-up after term until $\mathrm{T}+12$ wca, whereas those born AGA tended to show no increase in weight SDS after term. Continued length catch-up was demonstrated in both groups but was more marked in those born SGA.

Body composition was measured approximately $2 \mathrm{wk}$ after discharge in 68 out of the 77 enrolled infants using DEXA (Table 6). Infants in group A had the greatest LM, BMC, and $\% \mathrm{FM}$ but these differences were only significant between groups $\mathrm{A}$ and $\mathrm{B}$. These were partly confounded by the greater body weight in group A. When bone mineral was expressed as a proportion of lean mass $(\mathrm{BMC} / \mathrm{LM})$, group differences were no longer significant. There were no group differences at $\mathrm{T}+$ 12 wca. Re-analysis of the data excluding 13/68 discharge and $9 / 58 \mathrm{~T}+12$ wca scans of poor quality did not affect the results. Fifty-seven infants had scans at both time points that allowed

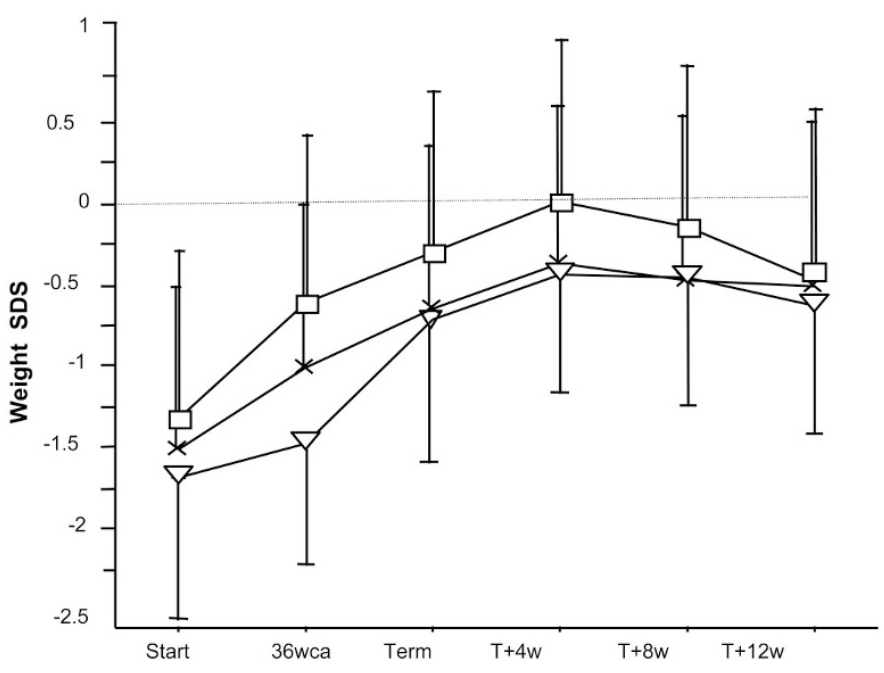

Figure 3. Change in the absolute weight SDS during the study period split by formula group. Data points represent mean $\pm \mathrm{SD} . \square-\mathrm{A} ; \nsucc-\mathrm{B} ; \neg-\mathrm{C}$.

calculation of weight gain composition, but no difference in grams per day increase in BMC, FM, or LM between the study groups was detected.

There were no sex difference in body composition at discharge except for \%FM, which was less in boys (boys, $14.5 \pm$ $4.2 \%$ versus girls, $17.5 \pm 4.4 \% ; p=0.006$ ). Increase in $\mathrm{BMC}$ was greater for boys than girls $(0.68 \pm 0.2 \mathrm{~g} / \mathrm{d}$ versus $0.55 \pm$ $0.16 \mathrm{~g} / \mathrm{d} ; p=0.009)$ as was increase in LM $(18.1 \pm 3.4 \mathrm{~g} / \mathrm{d}$ versus $15.9 \pm 2.3 \mathrm{~g} / \mathrm{d} ; p=0.007)$. By $\mathrm{T}+12$ wca, this resulted in boys having a greater BMC than girls $(107 \pm 25 \mathrm{~g}$ versus $95 \pm 15 \mathrm{~g} ; p=0.04)$ and $\mathrm{LM}(4317 \pm 474 \mathrm{~g}$ versus $4016 \pm 305 \mathrm{~g} ; p=0.007)$ that are likely to reflect differences in body weight. However, by $\mathrm{T}+12$ wca there was no longer any significant difference in \%FM between the sexes (boys, $25.1 \pm 5.6 \%$; girls, $26.1 \pm 5.6 \%$ ).

\section{DISCUSSION}

Previous controlled studies assessing protein requirements in preterm infants have examined growth during initial hospital stay (12-17). However, infants born preterm are usually discharged home before they have reached a corrected age of term. They also have accrued a major nutrient deficit that is not recouped before discharge (4). To accurately determine requirements, the effects of any intervention on growth need to be examined before and after initial hospital stay. This study provides comprehensive data on nutrient intake, growth, and body composition for preterm infants fed different levels of protein intake both before and after initial hospital discharge.

In our previous studies, we demonstrated that a formula containing $2.2 \mathrm{~g}$ protein and $80 \mathrm{kcal} / 100 \mathrm{~mL}$ improved growth when compared with a formula containing $1.4 \mathrm{~g}$ protein and 66 $\mathrm{kcal} / 100 \mathrm{~mL}(5,6)$. Improved growth appeared to be due to increased protein intake as caloric intakes were similar. However, in the current study we were unable to show an advantage of further increased protein density when fed until $\mathrm{T}+12 \mathrm{wca}$ and overall growth was similar to that in our earlier studies. Formula with higher protein-to-energy ratios $(3.3 \mathrm{~g} / 100 \mathrm{kcal})$ may promote faster weight gain in the smallest infants before 
Table 6. Body composition at discharge and $T+12 \mathrm{wca}$

\begin{tabular}{|c|c|c|c|}
\hline & Group A & Group B & Group C \\
\hline \multicolumn{4}{|l|}{ At discharge: } \\
\hline $\mathrm{n}$ & 22 & 23 & 23 \\
\hline PMA (days) & $278 \pm 8$ & $271 \pm 12$ & $275 \pm 15$ \\
\hline PNA (days) & $65 \pm 20$ & $57 \pm 20$ & $53 \pm 18$ \\
\hline $\mathrm{BMC}(\mathrm{g})$ & $49 \pm 13$ & $38 \pm 10$ & $41 \pm 14$ \\
\hline Bone area $\left(\mathrm{cm}^{2}\right)$ & $280 \pm 45$ & $254 \pm 45$ & $252 \pm 50$ \\
\hline $\operatorname{BMD}\left(\mathrm{g} / \mathrm{cm}^{2}\right)$ & $0.17 \pm 0.02$ & $0.15 \pm 0.02$ & $0.16 \pm 0.02$ \\
\hline $\mathrm{BMC} / \mathrm{LM}(\mathrm{g} / \mathrm{kg})$ & $17.4 \pm 3.0$ & $15.2 \pm 2.2$ & $15.8 \pm 2.7$ \\
\hline $\mathrm{FM}(\mathrm{g})$ & $594 \pm 276$ & $453 \pm 182$ & $497 \pm 243$ \\
\hline $\mathrm{LM}(\mathrm{g})$ & $2714 \pm 384$ & $2464 \pm 366$ & $2509 \pm 445$ \\
\hline Total mass (g) & $3357 \pm 622$ & $2956 \pm 536$ & $3047 \pm 683$ \\
\hline$\% \mathrm{FM}$ & $17.0 \pm 5.1$ & $14.8 \pm 3.7$ & $15.5 \pm 4.4$ \\
\hline \multicolumn{4}{|l|}{ At $\mathrm{T}+12$ wca: } \\
\hline $\mathrm{n}$ & 19 & 18 & 21 \\
\hline PMA (days) & $365 \pm 5$ & $367 \pm 8$ & $370 \pm 8$ \\
\hline PNA (days) & $151 \pm 16$ & $154 \pm 17$ & $148 \pm 15$ \\
\hline $\mathrm{BMC}(\mathrm{g})$ & $103 \pm 26$ & $104 \pm 26$ & $100 \pm 15$ \\
\hline Bone area $\left(\mathrm{cm}^{2}\right)$ & $432 \pm 63$ & $442 \pm 61$ & $437 \pm 42$ \\
\hline $\operatorname{BMD}\left(\mathrm{g} / \mathrm{cm}^{2}\right)$ & $0.24 \pm 0.03$ & $0.23 \pm 0.03$ & $0.22 \pm 0.04$ \\
\hline $\mathrm{BMC} / \mathrm{LM}(\mathrm{g} / \mathrm{kg})$ & $23.8 \pm 4.4$ & $24.3 \pm 5.2$ & $23.2 \pm 2.6$ \\
\hline $\mathrm{FM}(\mathrm{g})$ & $1493 \pm 509$ & $1569 \pm 575$ & $1459 \pm 386$ \\
\hline $\mathrm{LM}(\mathrm{g})$ & $4192 \pm 449$ & $4170 \pm 419$ & $4198 \pm 451$ \\
\hline Total mass (g) & $5788 \pm 877$ & $5844 \pm 841$ & $5757 \pm 648$ \\
\hline$\% \mathrm{FM}$ & $25.2 \pm 5.3$ & $26.3 \pm 6.6$ & $25.2 \pm 4.9$ \\
\hline
\end{tabular}

Data presented as mean \pm SD. BMC: bone mineral content; BMD: bone mineral density; FM: fat mass; LM: lean mass; PMA: post menstrual age; PNA: post natal age.

hospital discharge when compared with lower densities $(2.7$ $\mathrm{g} / 100 \mathrm{kcal}$ ), but further studies would be required to confirm this. The group differences were less dramatic than we expected based on the results of our previous studies that suggested that protein malnutrition is a major contributing factor to postnatal growth retardation in preterm infants (5). In the current study, the protein deficit at the point of entry into the study $(9-12 \mathrm{~g} / \mathrm{kg})$ was less than we expected from our previous data (13-23 g/kg) (4) and all groups showed higher rates of weight gain (37.2-41.6 g/d) compared with in utero references (30.7 $\mathrm{g} / \mathrm{d}$ at 32-36 wca) (11). These infants may, therefore, have been better nourished than in other studies and the effects of any intervention may have been less.

The data show that although the percentage of infants who were SGA increased dramatically from birth (13\%) to study enrollment (34\%), only $16 \%$ remained SGA at discharge and by term only $9 \%$ were SGA. We did not have accurate length data at birth and although over 50\% had length SDS $<-2$ at enrollment, only $22 \%$ had length SDS $<-2$ by term. Length retardation seemed more marked than weight retardation, but this may reflect the populations from which the reference data set was formed (9). The relationship between cumulative nutrient deficit and change in weight SDS at enrollment was weak and did not predict degree of catch-up. Recent studies have suggested that catch-up growth may be higher in AGA infants at discharge (18), however, our current study shows similar weight catch-up in both AGA and SGA infants by term but continuing catch-up after term mainly for those infants who were SGA at birth.

The primary outcome variable was weight gain between enrollment and $T+12$ wca. The data show that the rate of weight gain changed dramatically during this period of time, with the majority of catch-up taking place in the few weeks before and after discharge. The only apparent effects of higher protein intakes were during the first few weeks of the study. It is possible that because of the dramatic changes in weight gain during the study period, a formula designed to be optimal for early growth may not be optimal for later growth. This study, from approximately 30-34 wca to $\mathrm{T}+12 \mathrm{wca}$, covers the most dramatic ex utero growth of both the brain and the rest of the body. However, even this relatively short period of time encompasses a 2-fold change in protein requirements assessed using the factorial approach, although this assessment does not factor in any requirements for "catch-up." Estimates suggest that requirements decrease from $>3.5 \mathrm{~g} / \mathrm{kg} / \mathrm{d}$ at a weight of $<2000 \mathrm{~g}$ (2) to less than $1.5 \mathrm{~g} / \mathrm{kg} / \mathrm{d}$ in the third month for infants born at term (19). Therefore, whereas higher protein intakes using densities of $3.3 \mathrm{~g} / 100 \mathrm{kcal}$ may promote more rapid and appropriate weight gain (assessed by measurement of body composition) in the predischarge period, it would appear that a protein density of $2.7 \mathrm{~g} / 100 \mathrm{kcal}$ in the postdischarge period provides sufficient protein for continued growth and catch-up in this group of preterm infants. Whether higher protein intakes after discharge would benefit the smallest infants remains to be determined. Our previous data show that these infants regulate volume intake primarily on caloric density, with many infants consuming $>200 \mathrm{~mL} / \mathrm{kg} / \mathrm{d}$ when fed on demand (5). It is possible, therefore, that up-regulation of intake may partially compensate for earlier deficits.

This study is too small to examine whether there are sex differences in nutrient requirements. A significantly greater percentage FM at discharge in girls suggests that predischarge weight gain composition might differ between the sexes. The same may be true in the postdischarge period. Greater weight gain in boys ( $2 \mathrm{~g} / \mathrm{d}$ greater) was predominantly explained by a larger daily compositional increase in LM, and this may reflect the fact that boys had a greater volume intake than girls. Combined with the effects of postnatal age (which accounted for $\sim 20 \%$ of the variation in weight gain) it is possible that confounding by age and sex may have meant that the study was inadequately powered. Original sample size requirements were based on a significant difference in weight gain of $5 \mathrm{~g} / \mathrm{d}$. Analysis of the data after 25 infants had been randomized to each group suggested that continuing until 30 infants per group had been recruited would not make any difference to the primary outcome. The study was therefore discontinued at that point.

Recommendations on higher protein requirements are tempered by concerns of protein overload. SUN is closely correlated with protein intake when the whole cohort is considered, but for any individual infant the confidence intervals may be wide (Fig. 2). At intakes of up to $6 \mathrm{~g} / \mathrm{kg} / \mathrm{d}$ in this current study, three infants fed the formula with the highest protein density developed uremia, yet, none of these developed acidosis or raised ammonia, or had abnormal plasma amino acid profiles. Moreover, all infants continued to grow normally. Because SUN normalized without intervention, concerns for protein overload may not be as great as previously hypothesized (20), 
but do suggest that SUN and other biochemical measures requires careful consideration at these levels of protein intake.

It is possible that higher energy intakes would have been required to adequately assimilate the additional protein provided in the current study as suggested by others (14). Previous studies suggested that energy intakes of $\sim 150 \mathrm{kcal} / \mathrm{kg} / \mathrm{d}$ in association with higher protein intakes promoted improved weight gain compared with intakes of $120 \mathrm{kcal} / \mathrm{kg} / \mathrm{d}$ $(16,17,21)$. Several studies have also shown growth advantages to increased amounts of dietary protein $(13,15-17,21)$. However, the greatest differences were demonstrated in studies where intakes of $<3 \mathrm{~g} / \mathrm{kg} / \mathrm{d}$ were compared with those $>3.5$ $\mathrm{g} / \mathrm{kg} / \mathrm{d}$. There are few studies comparable to the current study, where intakes at the higher levels (e.g. $\sim 3.5 \mathrm{~g} / \mathrm{kg} / \mathrm{d}$ versus $\sim 4$ $\mathrm{g} / \mathrm{kg} / \mathrm{d}$ ) have been compared. Bhatia et al. (12) were unable to demonstrate differences in growth between formula with $2.2 \mathrm{~g}$, $2.7 \mathrm{~g}$, or $3.2 \mathrm{~g} / 100 \mathrm{kcal}$, but did show improvements in behavioral score, which might suggest later cognitive advantage. Fairey et al. (14) compared a protein density of $2.6 \mathrm{~g} / 100$ $\mathrm{kcal}(n=7)$ to $3.2 \mathrm{~g} / 100 \mathrm{kcal}(n=8)$ and were unable to show any differences in growth or body composition despite differences in nitrogen retention.

The current study suggests that higher protein intakes than currently used are safe, but clear advantages for growth particularly in the postdischarge period have yet to be conclusively demonstrated. Recent recommendations suggest maximum protein concentrations of $3.6 \mathrm{~g} / 100 \mathrm{kcal}$ (3). Energy intakes necessary to promote optimal growth remain uncertain with recommendations varying from 110 to $135 \mathrm{kcal} / \mathrm{kg} / \mathrm{d}$ (3). Further uncertainty exists with respect to the particular type of energy supplied, as studies have suggested that carbohydrate may be more effective than fat in enhancing growth and protein accretion (22). After discharge, lower protein densities appear adequate and although there appears to be no clear advantage to protein concentrations $>2.7 \mathrm{~g} / 100 \mathrm{kcal}$ in the infants we studied, it has yet to be determined whether the smallest infants may themselves benefit. Further studies with a larger sample size are needed if protein requirements are to be more precisely defined in these high-risk infants before discharge, and to identify the optimal formula composition in the postdischarge period.

Acknowledgments. The authors thank John C .Wells (Nutricia Ltd., Trowbridge, Wiltshire, U.K.), who provided invaluable support in the design and running of this study. We also thank the staff of Ward 35 Royal Victoria Infirmary, Newcastle upon Tyne, especially M.H. and S.J., and all the infants and their parents for their support and cooperation with this study.

\section{REFERENCES}

1. Anonymous 1987 Nutrition and feeding of preterm infants. Committee on Nutrition of the Preterm Infant, European Society of Paediatric Gastroenterology and Nutrition. Acta Paediatr Scand Suppl 336:1-14

2. Tsang R, Lucas A, Uauy R, Zlotkin S 1993 Nutritional Needs of the Preterm Infant: Scientific Basis and Practical Guidelines. Williams \& Wilkins, Baltimore, MD, pp 288-296

3. Klein CJ 2002 Nutrient requirements for preterm infant formulas. J Nutr 132:1395S$1577 \mathrm{~S}$

4. Embleton NE, Pang N, Cooke RJ 2001 Postnatal malnutrition and growth retardation: an inevitable consequence of current recommendations in preterm infants? Pediatrics 107:270-273

5. Cooke RJ, Griffin IJ, McCormick K, Wells JC, Smith JS, Robinson SJ, Leighton M 1998 Feeding preterm infants after hospital discharge: effect of dietary manipulation on nutrient intake and growth. Pediatr Res 43:355-360

6. Cooke RJ, McCormick K, Griffin IJ, Embleton ND, Faulkner K, Wells JC, Rawlings DC 1999 Feeding preterm infants after hospital discharge: effect of diet on body composition. Pediatr Res 46:461-464

7. Lucas A 1994 Role of nutritional programming in determining adult morbidity. Arch Dis Child 71:288-290

8. Koo WW, Walters J, Bush AJ 1995 Technical considerations of dual-energy X-ray absorptiometry-based bone mineral measurements for pediatric studies. J Bone Miner Res 10:1998-2004

9. Cole TJ, Freeman JV, Preece MA 1998 British 1990 growth reference centiles for weight, height, body mass index and head circumference fitted by maximum penalized likelihood. Stat Med 17:407-429

10. Matthews JN, Altman DG, Campbell MJ, Royston P 1990 Analysis of serial measurements in medical research. BMJ 300:230-235

11. Ziegler EE, O'Donnell AM, Nelson SE, Fomon SJ 1976 Body composition of the reference fetus. Growth 40:329-341

12. Bhatia J, Rassin DK, Cerreto MC, Bee DE 1991 Effect of protein/energy ratio on growth and behavior of premature infants: preliminary findings. J Pediatr 119:103110

13. Brooke OG, Wood C, Barley J 1982 Energy balance, nitrogen balance, and growth in preterm infants fed expressed breast milk, a premature infant formula, and two low-solute adapted formulae. Arch Dis Child 57:898-904

14. Fairey AK, Butte NF, Mehta N, Thotathuchery M, Schanler RJ, Heird WC 1997 Nutrient accretion in preterm infants fed formula with different protein: energy ratios. J Pediatr Gastroenterol Nutr 25:37-45

15. Hillman LS, Salmons SS, Erickson MM, Hansen JW, Hillman RE, Chesney R 1994 Calciuria and aminoaciduria in very low birth weight infants fed a high-mineral premature formula with varying levels of protein. J Pediatr 125:288-294

16. Kashyap S, Forsyth M, Zucker C, Ramakrishnan R, Dell RB, Heird WC 1986 Effects of varying protein and energy intakes on growth and metabolic response in low birth weight infants. J Pediatr 108:955-963

17. Kashyap S, Schulze KF, Forsyth M, Zucker C, Dell RB, Ramakrishnan R, Heird WC 1988 Growth, nutrient retention, and metabolic response in low birth weight infants fed varying intakes of protein and energy. J Pediatr 113:713-721

18. De Curtis M, Pieltain C, Rigo J 2002 Body composition in preterm infants fed standard term or enriched formula after hospital discharge. Eur J Nutr 41:177-182

19. Fomon S 1993 Nutrition of Normal Infants. Mosby-Year Book Inc., St. Louis, MO, pp 121-146

20. Boehm G, Lorenz I, Bergmann L, Muller DM, Beyreiss K 1987 Metabolic consequences of high protein intake in premature infants appropriate for gestational age. Biomed Biochim Acta 46:89-95

21. Schulze KF, Stefanski M, Masterson J, Spinnazola R, Ramakrishnan R, Dell RB, Heird WC 1987 Energy expenditure, energy balance, and composition of weight gain in low birth weight infants fed diets of different protein and energy content. J Pediatr 110:753-759

22. Kashyap S, Ohira-Kist K, Abildskov K, Towers HM, Sahni R, Ramakrishnan R, Schulze K 2001 Effects of quality of energy intake on growth and metabolic response of enterally fed low-birth-weight infants. Pediatr Res 50:390-397 